УДК $316.455 ; 331.1$

DOI: https://doi.org/10.37320/2415-3583/16.12

Овчарук О.М. кандидат економічних наук, доцент кафедри менеджменту Полтавська державна аграрна академія ORCID: https://orcid.org/0000-0002-3043-9271

\title{
ТЕОРЕТИКО-МЕТОДОЛОГІЧНІ ЗАСАДИ УПРАВЛІННЯ КОНФЛІКТАМИ В ТРУДОВОМУ КОЛЕКТИВІ
}

\begin{abstract}
Менеджмент українських підприємств стикається зі значними культурними ризиками і комунікативними бар'єрами. У зв'язку із ици управління конфліктами стає темою підвищеної уваги не тільки в теорії менеджменту, а й у практиці управління у иілому. Метою дослідження є узагальнення теоретико-методологічних положень виникнення та вирішення організаційних конфліктів. У статті зазначено, шо умовою виходу з економічної кризи для багатьох підприємств є саме конструктивний підхід до управління конфліктною взаємодією, оскільки в конфлікті від самого початку закладений потенціал для будь-якої організації. Здійснено огляд конкретних причин та базових складників організаційних конфліктів у трудовому колективі. Розглянуто методологію управління процесом конфлікту. Запропоновано профілактичні процедури в рамках організаційного середовища $з$ метою зниження рівня конфліктів в організаціях. У результаті дослідження встановлено, шчо будь-яка організація може піддаватися різним видам конфліктів залежно від рівня якості корпоративної культури, розмірів організації, особистісних характеристик керівників та членів колективу.
\end{abstract}

Ключові слова: кадри, конфлікти, менеджмент, організація, персонал, підприємство, трудовий колектив, управління конфліктами.

Постановка проблеми. Глобалізаційні процеси, зміна соціально-трудових відносин, розвиток нових форм власності і зростаюча конкуренція підвищують соціальну напруженість у сфері праці, активізуючи інтерес до проблем управління персоналом, зокрема до питання управління конфліктами в організаціях.

Сьогодні, коли національна економіка знаходиться у стадії радикального реформування, питання управління конфліктами викликають інтерес у багатьох дослідників. Ефективне управління конфліктами, по суті, означає роботу з управління продуктивністю праці.

Менеджмент українських підприємств стикається зі значними культурними ризиками i комунікативними бар'єрами. У зв'язку із цим управління конфліктами в трудовому колективі стає темою підвищеної уваги не тільки в теорії менеджменту, а й у практиці управління у цілому. У ситуації відставання теоретикометодологічної бази досліджень організаційного конфлікту від зростання якісних і кількісних показників міжнародних проєктів підприємств реального сектору національної економіки закладений великий потенціал і управлінський попит на дослідження 3 даної проблематики. У зв'язку із цим тема дослідження є актуальністю.

Аналіз останніх досліджень і публікацій. Сучасні теорії конфлікту були сформовані концептуальними роботами таких учених, як М. Вебер, М. Дейч, Г. Зіммель, Л. Козер, К. Маркс, У. Мастенбрук, Т. Парсонс, П. Сорокін, Г. Спенсер та ін.

Серед зарубіжних дослідників конфлікту можна виділити Е. Берна, С. Вільсона, А. Гелена (соціобіологічний напрям), А. Маслоу, 3. Фрейда (психологічний підхід), Х. Корнеліуса, Р. Фішера, Ш. Фейр, У. Юрі (міждисциплінарний підхід до дослідження конфліктів).

Аналізом теоретико-методологічних основ управління конфліктом займалися вітчизняні дослідники
О. Біловодська, Ю. Вакуленко, Л. Горбатюк, В. Кизима, Ю. Коврижко Т. Мостенська, В. Познаховський, І. Потапюк, О. Резнікова, М. Сьомич, І. Шульженко та iн. Зазначеними науковцями досліджувалися причини виникнення, способи та методи управління конфліктами.

Здебільшого зазначені вище напрацювання мають загальний характер, проте недостатньо конкретних рекомендацій щодо управління конфліктами. У цьому зв'язку зауважимо, що ставлення до конфліктів не є однозначним. Наприклад, Л. Балабанова та О. Сардак розглядають конфлікт як позитивне явище, оскільки організація містить у собі потенціал напруги, а отже, конфліктна за своєю природою. Учені зауважують, що «...вирішені конфліктні ситуації можуть стати засобом вирішення актуальних завдань» [1].

Н. Діденко [3], О. Криса [5], О. Резникова, Е. Карабаш [7] підкреслюють, що конфлікт - це «явище негативне, тому що він завдає значної шкоди ефективній взаємодії у групах та стає причиною втрат виробничих ресурсів і часу».

Проблеми організаційних конфліктів залишаються недостатньо розробленими, оскільки більшість авторів торкається іiі опосередковано, у рамках вирішення інших завдань дослідження.

Мета статті полягає в узагальненні теоретикометодологічних положень виникнення та вирішення організаційних конфліктів у трудовому колективі.

Виклад основного матеріалу. Будь-який конфлікт починається 3 певного збігу обставин, сукупності зовнішніх умов, в яких опинилися потенційні суб'єкти конфліктного протистояння. Прихований конфлікт може так і залишитися в латентній формі, якщо не трансформується в конфлікт, що відчувається або сприймається учасниками. Підвищення внутрішньої напруги в організації поряд із використанням механізмів подолання і відволікання уваги перероджує конфлікт у відкриту фазу [2, с. 114]. 
Управління конфліктами в менеджменті організації займає одне $з$ провідних місць, оскільки умови ринку постійно підігрівають конфліктну взаємодію, а їх високий організаційний складник дає змогу домогтися інноваційних, творчих результатів [8, с. 101].

Умовою виходу з економічної кризи для багатьох підприємств $є$ саме конструктивний підхід до управління конфліктною взаємодією, оскільки в конфлікті від самого початку закладений потенціал для будь-якої організації:

1) сигналізують про проблемні місця підприємства, які не створюють додаткової цінності для організації, виступаючи тим самим інструментом діагностики внутрішнього мікроклімату і стану організаційної культури;

2) в екстреній ситуації розкриваються реальні можливості колективу, лідери і лояльні співробітники, що дає змогу провести санацію організаційної системи;

3) за правильного управління конфліктна ситуація може призвести до підвищення продуктивності організації, оскільки основний акцент робиться не на їх викоріненні, а на аналізі глибинних організаційних протиріч;

4) різноманітність точок зору дає додаткову інформацію, допомагає виявити більше альтернатив і проблем [9].

Конструктивний підхід до вирішення конфлікту дає змогу розрядити емоційну напруженість, зблизити конфліктуючі сторони, підвищити продуктивність, стимулювати організаційні зміни, посилити взаємну довіру i терпимість співробітників по відношенню один до одного [10].

Відсутність уваги з боку вітчизняних дослідників на природу організаційного конфлікту призвела до гострого дефіциту ефективних практик і методів управління ними.

Управління конфліктами, на наше переконання, являє собою процес перетворення конфліктної площини з усуненням очагу виникнення, виключення можливості подальшого загострення, у тому числі деструктивних наслідків. Це специфічний вид управлінської активності, який входить у сферу управління персоналом, спрямований на усунення можливих причин конфліктних ситуацій.

Уважаємо, що знання етапів розвитку конфлікту сприятиме розробленню ефективної програми 3 його нейтралізації.

Серед конкретних причин організаційних конфліктів ми виділяємо такі:

1.Неточність правил i регламентів. Внесений у регламенти суб'єктивізм і помилки сприяють їх неповноті, знижують ефективність роботи організації та розмивають іiі структуру. Наприклад, розподіл функціональних обов'язків може бути невідповідним.

2.Розбіжність, відмінність або перетин інтересів членів організації. Об'єктивно можуть розходитися цілі та інтереси працівників і різних підрозділів в організаціях. Наприклад, працівники одного відділу розраховують на винагороду за розроблення перспективного проєкту; водночас і працівники іншого відділу організації також припускають отримання значної винагороди, якщо у виробництво приймуть їхній проєкт. Зіткнення різних інтересів призводить до блокади потреб одного з відділів, конкуренції між ними, а у разі появи агресії й до конфлікту.

3. Різниця у ціннісних орієнтаціях. Індивідуальні та групові цінності можуть мати різну значимість для членів організації. Так, одні працівники вважають цінністю цікаву і змістовну роботу, а інші орієнтовані тільки на отримання винагороди будь-яким способом. Очевидно, що відмінність у ціннісних орієнтаціях у ході спільної діяльності може призвести до конфлікту.

4. Різні форми економічної і соціальної нерівності. Слід відзначити, що саме нерівний розподіл цінностей (винагород, інформації, влади, визнання, престижу i т. д.) між окремими членами організації, групами та підрозділами служить лише підставою для виникнення конфлікту. Найважливішим моментом, що провокує виникнення і розвиток конфліктної ситуації з причин нерівності, слід уважати усвідомлення членами організації несправедливості розподілу винагороди і сформованих соціальних відносин (перш за все відносин влади - підпорядкування).

5.Незадоволеність відносинами між окремими структурними одиницями організації (тобто тим місцем або статусом, яке працівники або соціальні групи займають у структурі організації). Цей тип причин викликає структурні конфлікти.

Група причин, що носять суб'єктивний характер:

a) нечіткий розподіл прав і обов'язків членів організації;

б) неправильні дії одного або кількох членів організації, що завдають шкоди спільній справі або зривають досягнення спільної мети;

в) ситуаційна несумісність двох або більшого числа членів організації, що виявляється у невідповідності вчинків одного члена організації очікуванням, ціннісним установкам, життєвим правилам іншого (інших);

г) розбіжність у думках, оцінках, судженнях тих чи інших членів групи;

г) особиста неприязнь одного члена організації до іншого (інших), що заважає їх співпраці і досягненню спільної мети;

д) заздрість одного або кількох членів групи до успіхів, престижу, авторитету іншого, більш процвітаючого в будь-якому відношенні члена тієї ж організації;

е) психологічна несумісність двох або кількох членів даної організації.

Для вироблення релевантного інструментарію управління конфліктом необхідно розглянути організаційний конфлікт із базових складників (табл. 1).

Зарубіжні джерела свідчать про значне поширення практики управління організаційними конфліктами на основі інституційних форм за використання ідей суспільної злагоди і партнерства [11, с. 44]. В організації може бути введений певний механізм єдиної процедури вирішення конфлікту. Для його працездатності слід сформувати легітимну основу, іншими словами, визнання співробітниками правомірності і справедливості певної логістики дій, яка може розходитися навіть із нормативно-правовими нормами [4, с. 62].

Методологічно управління процесом конфлікту може здійснюватися ізольовано або комплексно. Це зумовлено специфікою ситуації й організації. Основні методи управління зводяться до декількох аспектів [2]: 
Таблиця 1 - Організаційний конфлікт із концептуальної позиції

\begin{tabular}{|c|c|}
\hline Базові складники організаційного конфлікту & Елементи \\
\hline \multirow{4}{*}{ Компонентна структура } & мотиваційний \\
\hline & когнітивний \\
\hline & вольовий \\
\hline & емоційний \\
\hline \multirow{3}{*}{ Структурні елементи } & причини/ситуація \\
\hline & стратегія поведінки \\
\hline & динаміка/прогноз \\
\hline \multirow{4}{*}{ Внутрішньоорганізаційні каталізатори } & упровадження інновацій \\
\hline & недосконалість комунікаційних каналів \\
\hline & недостатність ресурсів \\
\hline & похибки в управлінні \\
\hline \multirow{5}{*}{ Організаційний фон } & якість виробничих процесів \\
\hline & характер взаємодії персоналу \\
\hline & робочі місця \\
\hline & ставлення до робочого часу \\
\hline & мікроклімат у колективі \\
\hline \multirow{4}{*}{ Рівень конфлікту, що сприймається } & інтелектуальні здібності \\
\hline & самоконтроль/рефлексія \\
\hline & соціальний досвід \\
\hline & досвід переговорів \\
\hline \multirow{5}{*}{ Культура вирішення конфлікту } & готовність менеджменту почути персонал \\
\hline & органи самоврядування/спеціальні комісії \\
\hline & глибинне формулювання проблеми \\
\hline & інформаційна культура \\
\hline & $\begin{array}{l}\text { внутрішньоорганізаційні практики/ інституційні механізми роботи } 3 \\
\text { конфліктом }\end{array}$ \\
\hline
\end{tabular}

Джерело: узагальнено автором на основі [6]

1. Метод планування. Розглядає конфлікт у певній перспективі, що дає змогу оцінити характер наслідків для організаційної реальності, тим самим визначаючи якість подальшої технології по процесному управлінню конфліктом. Метод не передбачає безпосереднього активного впливу на процес, він формує концептуальне підгрунтя для його стратегічного розв'язання.

2. Метод організації. Мається на увазі певний характер активного впливу на конфлікт. В основі - управлінські технології, що трансформують процес конфлікту, установки і мотиваційні складники суб'єктів. Мішенню управлінського впливу виступають глибоко причинні зв'язки, що визначають не тільки сам факт виникнення конфліктної ситуації, а й якість ії протікання.

3. Метод контролю. Базується на аналізі, коли виділяється еталонна модель процесу конфлікту (iї критерії). Конфлікт фрагментується, ідентифікуються ті складники, які являють собою критерії бажаного стану конфліктного процесу. Подальша кореляція з реальним станом стає підставою для обгрунтування дій з управління процесом конфлікту.

Необхідно проводити профілактичні процедури в рамках організаційного середовища, щоб знизити рівень конфліктів:

1. Формування організаційної культури. Справедливий розподіл організаційних обов'язків і матеріальних благ, генерування позитивного трудового настрою і відчуття причетності кожного до даного колективу і справи, оптимізація взаємодії між структурними еле- ментами та співробітниками, балансування формальних і неформальних структур колективу.

2. Кадрова робота. Приведення у відповідність важливість справ структури організації, пошук і виховання лояльних співробітників, розстановка персоналу з урахуванням професійного і психологічного профілів працівника, чітке позиціонування посадових компетенцій, відповідальності і повноважень, підвищення кваліфікації працівників, їх особистісний ріст.

3. Робота 3 формування організаційної поведінки. Створення економічних стимулів, справедлива система заохочення, інформаційна політика і стиль спілкування з підлеглими.

Висновки. У результаті дослідження встановлено, що будь-яка організація може піддаватися різним видам конфліктів залежно від рівня якості корпоративної культури, розмірів організації, особистісних характеристик керівників та членів колективу.

Сфера запобігання конфлікту в трудовому колективі передбачає реалізацію таких лідерських якостей, як: повага до співробітників; постановка ясних i виконуваних завдань; оцінка успіхів виходячи 3 початкового положення справ; стримана критика, уникнення крайніх оціночних суджень; надання співробітникам неформального права на помилку; акцент на внутрішній мотивації, а не на тотальному контролі. При цьому діагностичними елементами передконфліктних явищ виступають групи індикаторів: економічні (зриви в термінах, виконання планів), емоційні (експресія, агресивність у поведінці), інтелек- 
туальні (незгода зі значущих питань). Менеджер має формувати комплекс заходів щодо запобігання конфлікту, використовуючи базові принципи: блокування дій однієї або всього комплексу причин, виховний вплив, переконання в спільності цілей, поділ спірних моментів тощо.

\section{Список використаних джерел:}

1. Балабанова Л.В., Сардак О.В. Управління персоналом. URL: http://www.twirpx.com/file/544700/ (дата звернення: 21.01.2021).

2. Берн Э. Игры, в которые играют люди. Люди, которые играют в игры / пер. с англ. А. Грузберга. Москва : Эксмо, 2008. $576 \mathrm{c}$.

3. Діденко Н.В. Система антикризового менеджменту персоналу в сучасних умовах. URL: irbis-nbuv.gov.ua〉cgi-bin/irbis nbuv/cgiirbis/ (дата звернення: 18.01.2021).

4. Калініченко Т.І. Теоретичні підходи до тлумачення організаційної культури. Держава та регіони. Серія «Економіка та підприємниитво». 2010. № 3. С. 62-67.

5. Криса О.Й. Управління конфліктами як фактор підвищення конкурентоспроможності підприємств. URL: http://vlp.com.ua/files/52_0.pdf (дата звернення: 02.02.2021).

6. Потапюк І.П., Даниленко К.О., Мокієнко С.О. Корпоративна культура як складник стратегічного управління персоналом підприємства. Приазовський економічний вісник. 2017. № 5(05). С. 170-175. URL: http://pev.kpu.zp.ua/vypusk-5-05 (дата 3вернення: 01.02.2021).

7. Резникова О.С., Карабаш Э.Р. Управление конфликтами в организации. Проблемы экономики и менеджмента. 2017. URL: https://cyberleninka.ru/article/n/upravlenie-konfliktami-v-organizatsii-5/viewer (дата звернення: 19.01.2021).

8. Сазонова Т.О., Шульженко І.В., Хавронюк В.Ю. Управління конфліктами, як важливий елемент організаційної культури сучасної організації. Інфраструктура ринку. 2020. Вип. 47. С. 101-105.

9. Сазонова Т.О., Михайлова О.В. Формування стратегії управління конфліктами організації в умовах сучасного бізнес-середовища. Глобальні та національні проблеми економіки. 2017. Bun. 20. C. 539-542. URL: http://global-national.in.ua/ archive/20-2017/110.pdf (дата звернення: 12.01.2021).

10. Управління конфліктами при взаємодії органів влади та громадськості / М.І. Сьомич та ін. Публічне адміністрування та наиіональна безпека. 2020. № 8(16). URL: https://www.inter-nauka.com/uploads/public/16123812147877.pdf (дата звернення: 04.02.2021).

11. Шейнов В.П. Конфликты в нашей жизни и их разрешение. Минск : Амалфея, 2006. 118 с.

\section{References:}

1. Balabanova L.V., Sardak O.V. Upravlinnia personalom [Personnel management]. Available at: http://www.twirpx.com/ file/544700/ (accessed 21 January 2021).

2. Bern E. (2008) Ihri, v kotorie ihraiut liudy. Liudy, kotoie ihraiut v ihri [Games that people play. People who play games]. Moscow: Eksmo (in Russian)

3. Didenko N.V. Systema antykryzovoho menedzhmentu personalu v suchasnykh umovakh. [The system of crisis management of personnel in modern conditions]. Available at: irbis-nbuv.gov.ua>cgi-bin/irbis_nbuv/cgiirbis/(accessed 28 January 2021).

4. Kalinichenko T.I. (2010) Teoretychni pidkhody do tlumachennia orhanizatsiinoi kultury [Theoretical approaches to the interpretation of organizational culture]. Derzhava ta rehiony. Seriia: Ekonomika ta pidpryiemnytstvo, no. 3, pp. 62-67.

5. Krysa O.Y. (2008) Upravlinnia konfliktamy yak faktor pidvyshchennia konkurentospromozhnosti pidpryiemstv [Conflict management as a factor in increasing the competitiveness of enterprises]. Available at: http://vlp.com.ua/files/52_0.pdf (accessed 05 February 2021).

6. Potapiuk I.P., Danylenko K.O., Mokiienko Ye.O. (2017) Korporatyvna kultura yak skladnyk stratehichnoho upravlinnia personalom pidpryiemstva [Corporate culture as an integral part of the enterprise human resource management strategy]. Market infrastructure, no. 5, pp. 170-175. Available at: http://pev.kpu.zp.ua/vypusk-5-05 (accessed 01 February 2021).

7. Reznykova O.S., Karabash E.R. (2017) Upravlenye konflyktamy v orhanyzatsyy [Conflict management in the organization]. Problemy ekonomyky i menedzhmenta. Available at: https://cyberleninka.ru/article/n/uprav leniekonfliktami-v-organizatsii-5/viewer (accessed 17 January 2021).

8. Sazonova T.O., Shulzhenko I.V., Khavroniuk V.Yu. (2020) Upravlinnia konfliktamy, yak vazhlyvyi element orhanizatsiinoi kultury suchasnoi orhanizatsii [Conflict management as an important element of the organizational culture of a modern organization]. Infrastruktura rynku, vol. 47, pp. 101-105.

9. Sazonova T.O., Mykhailova O.V. (2017) Formuvannia stratehii upravlinnia konfliktamy orhanizatsii v umovakh suchasnoho biznes-seredovyshcha [Formation of conflict management strategy in condition of modern business environment]. Hlobalni ta natsionalni problemy ekonomiky, no. 20. Available at: http://global-national.in.ua/archive/20-2017/110.pdf (accessed 12 January 2021).

10. Somych M.I., Vakulenko Yu.V., Horbatiuk L.M., Kovryzhko Yu.A. (2020) Upravlinnia konfliktamy pry vzaiemodii orhaniv vlady ta hromadskosti [Conflict management in the interaction of government and the public]. Elektronne naukove vydannia «Publichne administruvannia ta natsionalna bezpeka», no. 8 (16). Available at: https://www.inter-nauka.com/uploads/public/16123812147877.pdf (accessed 04 February 2021).

11. Sheinov V.P. (2006) Konflykti v nashei zhyzny i ykh razreshenye Formuvannia dokhodiv pratsivnykiv pidpryiemstv [Conflicts in our lives and their resolution]. Minsk: Amalfeia. 
Ovcharuk Olena

Poltava State Agrarian Academy

\section{THEORETICAL AND METHODOLOGICAL FUNDAMENTALS OF CONFLICT MANAGEMENT IN THE WORKFORCE}

The management of Ukrainian enterprises faces significant cultural risks and communication barriers. In this regard, conflict management in the workforce is a topic of increased attention not only in management theory but also in management practice in general. Today, when the national economy is in the process of radical reform, conflict management is of interest to many researchers. Effective conflict management, in fact, means work on performance management. The problems of organizational conflicts remain underdeveloped, as most authors study it indirectly, solving other research problems. The aim of the study is to generalize theoretical and methodological provisions of the emergence and resolution of organizational conflicts in the workforce. The article specifies that condition to overcome economic crisis for many enterprises is a constructive approach to managing conflict interaction, as a conflict itself is inherent for any organization. A constructive approach to conflict resolution allows to relieve emotional tension, bring the conflicting parties together, increase productivity, stimulate organizational change, strengthen mutual trust and tolerance of employees toward one another. Conflict management in the workforce, according to the author, is a process of transformation of conflict plane with the easing hotbed of tension, exclusion of the possibility of further deterioration, including destructive consequences. It is a specific type of management activity, which is a part of personnel management, aimed at eliminating the possible causes of conflict situations. The article reviews the specific causes and basic components of organizational conflicts. The methodology of conflict management is considered. Preventive measures within the organizational environment are proposed in order to reduce the level of conflicts in organizations. The study has found that any organization can be subject to different types of conflicts depending on the level of corporate culture, the size of organization, personal characteristics of managers and employees.

Key words: staff members, conflicts, management, organization, personnel, enterprise, workforce, conflict management.

JEL classification: C78, J52, J53 